\title{
明治時代前半における洋釘の普及と和釷併用の背景
}

\section{STUDY ON THE DIFFUSION OF THE WESTERN NAIL AND BACKGROUND OF THE COMBINED ON THE USE OF THE JAPANESE NAIL IN THE FIRST HALF OF THE MEIJI PERIOD}

\author{
平山育男*1
}

\section{Ikuo HIRAYAMA}

\begin{abstract}
This article examined the spread of nails in the first half of the Meiji era, based on the business situation in Yokohama published in the Chugai-bukka-shimpo and Chugai-shogyo-shimpo. The following points became clear.

According to the description of the Chugai paper in Yokohama from the Meiji 10s to the mid-Meiji 20s, the nails were identified as "iron nail", "nail-rod" and "nail". Japanese nails were manufactured using imported nail iron. These Japanese nails and imported western nails circulated, and the combined use of Japanese nails and western nails was seen in the late Meiji 10s.
\end{abstract}

\section{Keywords : iron nail, nail iron, nail-rod}

鉄釘, 釘鉄, 釘棹

\section{1 はじめに}

筆者は、前稿までで明治時代における洋釘の普及を価格の観点か ら考察している。その結果、『中外物価新報』及び後続紙となる『中 外商業新報』(以下、両紙を総称する場合、“『中外』 紙”) 注1) に掲 載される横浜商況の記載などから、少なくとも明治 15 (1885) 年以後 において最も使用量の多かった 1 吋半の長さを有する洋釷について 価格の変遷を明らかにしている。そして、これを明治 8(1875) 年に おける開智学校の見積資料にある同じ長さとなる和釗の価格注2) と 比較すると、既に明治 15 (1885) 年の段階における洋釷の価格は明治 8 (1875) 年における和釷の価格に対し $1 / 21$ となっており参考5)、更に 明治 25 (1892) 年以後は宮本又次らによる『明治期大阪卸売物価資料 (4)』(以下、『物価資料 (4)』) 注3)などにより、明治時代末には $1 / 50$ 程であったことを考察した参考4)

ところで明治 15 (1885) 年以前の段階における、洋釷の普及はどの ような状況であったのか、との疑問が残る。この点について安田善 三郎による『釘』（以下、『釘』）では

明治十年ころ、横浜百六十八番館（商館名不明） 一見本四五十 樽の着いたのが、商品として輸入された始めなさうであります 注4)

とされ、明治 10 (1877) 年の横浜商館による輸入の情報が伝聞の形で 示される注5)。一方、関西では、梅本商行による『釘とともに歩んだ 120 年』において
現在の丸釘、その当時の洋釷は何時どのような経路で日本に入 ったのであろうか。明治 5 年、当社斯業創業の三代目梅本利右 衛門が神戸の商館（注）を通じて初めて輸入し、国内に広めた ことになっている。

(注) 明治 7 年 12 月二代目死去に際し、香㚗受領の記録に「神 戸 10 番・アーレス社、同 46 番・エストマン商会、同 48 番・ モラカンブ商会、同 56 番フレヴオ商会と外国商館の名前が記 されてあるので、その中の 1 社や 4 社全部から買ったらしい が明らかではない注6

として、明治 $5(1872)$ 年頃の梅本による洋釘輸入の可能性を示寸。 但し、以上の記載はいずれも確実な根拠に基づくものではない。一 方、筆者らは明治 10 (1877) 年代後半から明治 20 (1887) 年代にかけて、 角釘となる和釷と丸釘となる洋釷が併用されたことを既に報告参考2) している注7)ものの、これ程の価格差があったにもかかわらず、角釘 と丸釷が一定期間、併用された理由を明示できてはいない。

そこで、本稿では明治時代前半における洋釷の普及について実態 に即して考察を行うとともに、角釷と丸釷が併用された背景を明ら かにすることを目的とする。

\section{2 考察に用いる資料と概要 \\ 2-1 本稿で用いた資料}

かつて、明治時代において洋釷の価格を記寸資料として大阪大学

\footnotetext{
*1 長岡造形大学造形学部 教授・博士(工学)、博士(造形) Prof., Faculty of Design, Nagaoka Institute of Design, Dr.Eng., Dr.Design
} 
物価史研究会の宮本又次らによる『物価資料 (4)』を用いた。但し、 これは明治 25 (1892) 年以後における統計資料をまとめたものであ るため、それ以前の状況を知るために明治 9 (1876) 年創刊の『中外』 紙における横浜商沉の鉄類などに掲載される釘類の記載を用いた。 そして前稿ではこの内、特に明治 15 (1882) 年から明治 24 (1891) 年の 10 年間において 1 寸 2 分の長さとなる丸釷の価格を抽出し、その変 遷を追い考察を行った参考5)

ところで、明治 9 (1876) 年から明治 24(1891) 年における『中外』 紙の記載を通読すると、1 寸 2 分となる丸釘の価格以外についても 輸入された釷類について多くの情報を得ることができた。そこで、 本稿ではこの期間における『中外』紙の横浜商況に示された釷類の 記載を整理することで、当該期間における洋釘の普及について考察 を進めることとする。

\section{2-2『中外』紙の横浜商況に見る釘類の概要}

具体的には、明治 9 (1876) 年から明治 $24(1891)$ 年における『中外』 紙の横浜商況における鉄類などの記載中、“釷”とする記事を網羅的 に拾い上げて検討を加えた。なお、大別するとこの期間では、

(1) 釘・鉄釘・丸釷 (以下、総称する場合は “鉄釷類”)

(2) 釘棹・釘棹鉄 (以下、総称する場合は “釘棹類”)

(3) 釷鉄・釬鉄角・釘角 (以下、総称寸る場合は “釷鉄類”) とする 3 種類の記載を確認することができた。以下ではこの 3 項目 を中心に、当該期間における洋釷の普及を考察する。

\section{3 明治 $9(1876)$ 年から明治 $24(1891)$ 年の『中外』紙横浜商況に 見る鉄釘類}

明治 $9(1876)$ 年の創刊から明治 24 (1891) 年の『中外』紙の横浜商 況における（1）鉄釘類、（2）釘棹類、（3）釘鉄類について概要を Table 1 に示した。以下、各項目の記載内容に検討を加える。

\section{3-1 釘·鉄釘・丸釘}

鉄釘類の記載は、明治 10 (1877) 年 6 月 23 日付の横浜商況に初め て見ることができる。記載は

前二週（四日ヨリ十六日迄）当湊引取物概要《中略》○釷百三 十五箱注 8

とあり、この項目に記載される商品がいずれも輸入品であるため、 この時点での “釷”、即ち洋釷の輸入取扱を確認できる。更に同年 12 月 25 日付の記載でも

前一週（自三日至八日）当港引取物概略《中略》○釘二百樽注9) とあり、明治 $10(1877)$ 年における 100 箱以上となる釷の取引を 2 度 に渡り確認することができる。続いて明治 11 (1878) 年は 1 月 16 日 付の記載に

黄銅釘八百四十斤《中略》鉄釘金八百斤注10)

とあり、明治 11 (1878) 年は 1 月 23 日付の記載には

鉄釷二万千百斤注11)

とある。明治 $12(1879)$ 年では鉄釘については 3 例で“鉄釘一樽”注 12)、 “洋鉄釷十四多” 注13)、“鉄釷三十多” 注14)、“鉄釘百斤七刀” 注15) とする記載があり、丸釷については 2 例“鉄丸釘四分五分込八十多” 注16)、“鉄丸釘” 注17)で、鉄釷類では合計 5 例の記載が見ることがで きる。明治 13(1880) 年に “鉄釷類” の記載は見られず、明治 14(1881) 年は “鉄釷”注18) とする 1 例のみの記載しか確認できないが、“丸釷” を明治 $15(1882)$ 年は 5 例、明治 16 (1883) 年は 10 例、明治 17 (1884)
年は 27 例を確認でき、この頃からいわゆる丸釘の輸入が本格化した と見ることができる。

このように、輸入された鉄釗類は当初、単に “鉄釷”などと呼称 されたものの、在来の角釘と差別化するためであろうか、明治 $12(1879)$ 年 5 月 28 日付の記載を初例として “丸釷” とする呼称を確 認することができる。

なお、本稿では以下、この鉄釷類を “輸入丸釗”と称する。

\section{3-2 釘棹 · 釘棹鉄 \\ 3-2-1 釘棹類の輸入}

釘棹について記載の初見は明治 10 (1877) 年 3 月 31 日付の記事に

釘棹八二弗七分五厘 5 三弗壱分注19)

とある。続いて同年 7 月 28 日付の記載では

釘棹八 (一担二付) 二弗七分ヨリ三弗迄ニテ更二取引ヨロシ注20) とあるため、鉄棹の数詞には “担”を用いたことが分かる。ここで 1 担は約 $60 \mathrm{~kg}$ と考える 注21)。以後、同年 8 月 11 日付の横浜商況にも “釷棹”の記載があり、明治 11(1878) 年には 6 例、明治 12 (1879) 年には 2 例、いずれも “釷棹鉄”の記載を見ることができる。また、 明治 $11(1878)$ 年 7 月 17 日付の記載では

釷棹鉄ベルジュム製ノ毛宅低価ニテ百噸程ノ取組アリ注22) とあり、ベルギーからの輸入品とすることができる。一方、明治 11(1878) 年 11 月 30 日付の記載では

スタッフォルド州ノ釗棹鉄モ亦売レロ宜シ注23) とあり、イギリスからの輸入とすることができる。

ところで、明治 $10(1877)$ 年 10 月 6 日付の記載には

釷鉄ハ少シ騰貴シ一担二付取交物八二弗七分ヨリ三弗注24)

とあり、同年 12 月 28 日付の商況でも

釘鉄八一担二付二弗六分五厘ヨリ三弗迄注25)

とあるが、後述する “釘鉄” は、この前後では

釗鉄二万五千斤注26)

など、“厅”による重量が示されるため、これも釷棹を指すものと考 えた。なお、明治 11 (1878) 年 9 月 4 日付の横浜商況では “棹鉄” と する商品も見ることができる。

\section{3-2-2 釘棹とは}

それでは、釘棹とはどのような製品であったのだろうか。

字面だけで考えると「棹」とは円筒状のものと考えることもでき、 歴史的には「等㧝鉒」として、竹筒に金銀を溶かし円柱状にしたもの が中世末から近世初期、国内には存在した注27)ため、「棹鉄」とは円 柱状の鉄材で、更に “釘棹鉄” とは釷用の棹鉄、即ち丸釷を製造す るための棒状の鉄材と考えることもできよう。

但し、英字紙では同時代の記事に

Nai1-rod[和訳 : 釷棹 $]^{\text {注28) }}$

の記載があり、この訳語と考えるのが妥当であろう。

ところで、この時代、輸入された鉄材を用いて、いわゆる丸釷が 国内において製造されていたのだろうか。この点について明治 $13(1880)$ 年 2 月 13 日付『朝日新聞』には

○南区瓦屋町四番丁岩重某八五千円の資本金を投じ手製の器械 を以て舶来模擬の釷製造せしが価が廉て且舶来品と異なる所 なけれバ余程能売別けると云ふ注29)

とある。また、明治 $13(1880)$ 年 3 月 14 日付『朝日新聞』には大阪 の砲兵工廠におけるものとして 
Table 1 The report of the nail etc. at the Yokohama-market of the "Chugai" paper from 1877 to 1891 明治 $10(1877)$ 年から明治 $24(1891)$ 年の『中外』紙 横浜商況における釘類の記事

Table 1-1 The report of "Tetukugi-rui" 鉄釬類の記事

\begin{tabular}{|c|c|c|c|c|c|c|c|c|c|}
\hline & & & & & \multirow{3}{*}{\begin{tabular}{|l}
$09 / 05-\mathrm{S} 4 \mathrm{RN}$ \\
$10 / 03-\mathrm{S} 4 \mathrm{RN}$ \\
\end{tabular}} & \multirow{3}{*}{\begin{tabular}{|l|}
$09 / 11-\mathrm{S} 4 \mathrm{RN}$ \\
$10 / 09-\mathrm{S} 4 \mathrm{RN}$ \\
\end{tabular}} & \multirow{3}{*}{\begin{tabular}{|l}
$09 / 15-\mathrm{S} 4 \mathrm{RN}$ \\
$10 / 13-\mathrm{S} 4 \mathrm{RN}$ \\
\end{tabular}} \\
\hline \multicolumn{2}{|l|}{ Meiji10 1877} & & & & $08 / 29-\mathrm{S} 4 \mathrm{RN}$ & 09/01-S4 RN & & & \\
\hline $06 / 23-59 \mathrm{~N}$ & $12 / 25-187 \mathrm{~N}$ & & & & $09 / 20-\mathrm{S} 4 \mathrm{RN}$ & 09/29-S4 RN & & & \\
\hline \multicolumn{2}{|l|}{ Meiji11 1878 } & & & & 10/19-S4 RN & $10 / 25-\mathrm{S} 4 \mathrm{RN}$ & $11 / 09-\mathrm{S} 4 \mathrm{RN}$ & $11 / 22-\mathrm{S} 4 \mathrm{RN}$ & $12 / 07-\mathrm{S} 4 \mathrm{RN}$ \\
\hline $01 / 16-15 \mathrm{SN}$ & $01 / 23-23 \mathrm{SN}$ & & & & $12 / 15-\mathrm{S} 4 \mathrm{RN}$ & & & & \\
\hline \multicolumn{5}{|l|}{ Meiji12 1879} & \multicolumn{5}{|l|}{ Mejij23 1890} \\
\hline $04 / 23-127 \mathrm{SN}$ & $05 / 07-143 \mathrm{SN}$ & 05/28-167 RN & $10 / 01-311 \mathrm{SN}$ & $12 / 10-391 \mathrm{RN}$ & $01 / 09-54 \mathrm{RN}$ & $01 / 19-\mathrm{S} 4 \mathrm{RN}$ & $01 / 26-\mathrm{S} 4 \mathrm{RN}$ & $02 / 09-\mathrm{S} 4 \mathrm{RN}$ & $02 / 21-\mathrm{S} 4 \mathrm{RN}$ \\
\hline \multicolumn{5}{|c|}{ Meiji13 1880} & $02 / 27-\mathrm{S} 4 \mathrm{RN}$ & 03/04-S4 RN & $03 / 09-\mathrm{S} 4 \mathrm{RN}$ & $03 / 13-\mathrm{S} 4 \mathrm{RN}$ & $03 / 26-\mathrm{S} 4 \mathrm{SN}$ \\
\hline \multicolumn{5}{|l|}{ Mejij14 1881} & $04 / 01-\mathrm{S} 4 \mathrm{SN}$ & 04/06-S4 RN & $04 / 12-\mathrm{S} 4 \mathrm{RN}$ & 05/24-S4 RN & $05 / 31-\mathrm{S} 4 \mathrm{RN}$ \\
\hline \multicolumn{5}{|l|}{$11 / 16-263 \mathrm{SN}$} & 06/05-S4 RN & $06 / 12-\mathrm{S} 4 \mathrm{RN}$ & $08 / 23-\mathrm{S} 4 \mathrm{RN}$ & $08 / 30-\mathrm{S} 4 \mathrm{RN}$ & $09 / 04-\mathrm{S} 4 \mathrm{RN}$ \\
\hline Meiji15 1882 & & & & & $10 / 01-\mathrm{S} 4 \mathrm{RN}$ & $10 / 25-\mathrm{S} 4 \mathrm{RN}$ & $11 / 02-\mathrm{S} 4 \mathrm{RN}$ & $11 / 08-\mathrm{S} 4 \mathrm{RN}$ & $11 / 13-\mathrm{S} 4 \mathrm{RN}$ \\
\hline $05 / 10-143 \mathrm{RN}$ & $07 / 18-227 \mathrm{RN}$ & 09/19-335 RN & $11 / 04-407 \mathrm{RN}$ & $12 / 23-487 \mathrm{RN}$ & \begin{tabular}{|l}
$12 / 06-54 \mathrm{RN}$ \\
\end{tabular} & & & & \\
\hline Mejij16 1883 & & & & & Mejij24 1891 & & & & \\
\hline $01 / 16-23 \mathrm{RN}$ & $05 / 10-209 \mathrm{RN}$ & $06 / 02-249 \mathrm{RN}$ & 06/19-277 RN & $07 / 07-309 \mathrm{RN}$ & $03 / 27-\mathrm{S} 4 \mathrm{RN}$ & 04/21-S4 RN & 06/11-S4 RN & 07/09-S4 RN & 07/18-S4 RN \\
\hline $08 / 07-361 \mathrm{RN}$ & $10 / 13-477 \mathrm{RN}$ & $10 / 16-481 \mathrm{RN}$ & $10 / 20-489 \mathrm{RN}$ & $11 / 22-541 \mathrm{RN}$ & $07 / 19-\mathrm{S} 4 \mathrm{RN}$ & 08/01-S4 RN & 08/14-S4 RN & 08/29-S4 RN & 09/29-S4 RN \\
\hline Meiji17 1884 & & & & & $10 / 04-S 4$ RN & 10/09-S4 RN & $10 / 11-\mathrm{S} 4 \mathrm{RN}$ & $11 / 06-\mathrm{S} 4 \mathrm{RN}$ & $11 / 08-\mathrm{S} 4 \mathrm{RN}$ \\
\hline $01 / 10-11 \mathrm{RN}$ & $01 / 15-19 \mathrm{RN}$ & $01 / 17-23 \mathrm{RN}$ & $01 / 24-35 \mathrm{RN}$ & $01 / 31-47 \mathrm{RN}$ & 11/13-S4 RN & & & & \\
\hline 02/16-75 RN & $02 / 26-91$ RN & 03/04-103 RN & $03 / 11-115 \mathrm{RN}$ & $03 / 13-119 \mathrm{RN}$ & & & & & \\
\hline $03 / 22-131 \mathrm{RN}$ & $04 / 15-167 \mathrm{RN}$ & $05 / 15-195 \mathrm{RN}$ & $05 / 10-211 \mathrm{RN}$ & $05 / 15-219 \mathrm{RN}$ & 美 & he descripti & Ho hux & tis & \\
\hline $05 / 27-239 \mathrm{RN}$ & $06 / 03-251 \mathrm{RN}$ & $06 / 05-255 \mathrm{RN}$ & $07 / 08-311 \mathrm{RN}$ & $08 / 13-3 \mathrm{RN}$ & 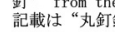 & であるか & 価格より & と判断でき & \\
\hline 08/19-3 RN & $08 / 27-3 \mathrm{SN}$ & 10/16-3 RN & $10 / 25-3 \mathrm{RN}$ & $10 / 30-3$ RNي1 & & the description & in is " & is $\mathrm{c}$ & 1 to be “丸 \\
\hline $11 / 06-3 \mathrm{RN}$ & $11 / 27-3$ RN*2 & $12 / 25-3 \mathrm{RN} * 3$ & & & 䚺 & める & ta & 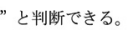 & \\
\hline Mejij18 1885 & & & & & & & & & \\
\hline $01 / 06-3 \mathrm{RN}$ & 02/07-3 RN & $02 / 21-3 \mathrm{RN}$ & $03 / 10-3 \mathrm{RN}$ & $03 / 26-3 \mathrm{RN}$ & & & & & \\
\hline $04 / 28-3 \mathrm{RN}$ & 05/26-3 RN & $05 / 30-3 \mathrm{RN}$ & 06/04-3 RN & 06/09-3 RN & 金]棹類0 & & & & \\
\hline 06/11-3 RN & 07/04-3 RN & $07 / 22-3$ RN & 07/24-3 RN & $07 / 29-3 \mathrm{RN}$ & Meivi10 1877 & & & & \\
\hline $08 / 09-3 \mathrm{RN}$ & 08/13-3 RN & $08 / 14-3 \mathrm{RN}$ & $08 / 23-3 \mathrm{RN}$ & $08 / 25-3 \mathrm{RN}$ & $03 / 31-50 \mathrm{NR}$ & $07 / 28-110 \mathrm{NR}$ & $08 / 11-118 \mathrm{NR}$ & $10 / 06-150$ NS $* 01$ & 1 12/28-191 NS *0 \\
\hline $09 / 27-3 \mathrm{RN}$ & $09 / 30-3 \mathrm{RN}$ & $10 / 22-3$ RY & $10 / 30-3 \mathrm{RN}$ & $11 / 03-3 \mathrm{RN}$ & \begin{tabular}{|l|} 
Meiji11 1878 \\
\end{tabular} & & & & \\
\hline $11 / 1-3 \mathrm{RN}$ & $11 / 20-3 \mathrm{RN}$ & $11 / 26-3 \mathrm{RN}$ & $12 / 02-3 \mathrm{RN}$ & $12 / 19-3 \mathrm{RN}$ & $07 / 17-215$ NRS & 09/04/271 RS & 09/21-291 NRS & $10 / 02-303$ RS & $10 / 16-319$ NRS \\
\hline $12 / 27-3 \mathrm{RN}$ & & & & & \begin{tabular}{|ll}
$11 / 30-367 \mathrm{NRS}$ \\
\end{tabular} & 12/14-383 NRS & $12 / 25-395$ NRS & & \\
\hline Mejij19 1886 & & & & & \begin{tabular}{|l|} 
Meij12 1879 \\
\end{tabular} & & & & \\
\hline $01 / 07-3 \mathrm{RN}$ & $01 / 15-3 \mathrm{RN}$ & $01 / 16-3 \mathrm{RN}$ & $02 / 06-3 \mathrm{RN}$ & 02/16-3 RN & 202/15-51 NRS & 03/08-75 NRS & & & \\
\hline $03 / 21-3 \mathrm{RN}$ & 03/23-3 RN & 04/08-3 RN & $04 / 30-3 \mathrm{RN}$ & 05/09-3 RN & & & & & \\
\hline $05 / 16-3 \mathrm{RN}$ & $05 / 28-3 \mathrm{RN}$ & 06/05-3 RN & $06 / 12-3 \mathrm{RN}$ & 06/19-3 RN & & 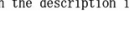 & $r^{2}+2>$ & & . \\
\hline 07/04-3 RN & $07 / 10-3 \mathrm{RN}$ & $07 / 24-3 \mathrm{RN}$ & $07 / 31-3 \mathrm{RN}$ & $08 / 05-3 \mathrm{RN}$ & 記载は“解鉄” & 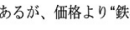 & 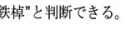 & & \\
\hline $08 / 13-3 \mathrm{RN}$ & 08/19-3 RN & $08 / 21-3 \mathrm{RN}$ & 09/01-3 RN & 09/23-3 RN & & & & & \\
\hline $10 / 01-3 \mathrm{RN}$ & $10 / 06-3 \mathrm{RN}$ & $10 / 09-3 \mathrm{RN}$ & $10 / 12-3 \mathrm{RN}$ & $10 / 21-3 \mathrm{RN}$ & & & & & \\
\hline $10 / 27-3 \mathrm{RN}$ & $10 / 30-3 \mathrm{RN}$ & $11 / 03-3 \mathrm{RN}$ & $11 / 18-3 \mathrm{RN}$ & $11 / 27-3 \mathrm{RN}$ & 金]鉄類の & 記事 & & & \\
\hline $12 / 02-3 \mathrm{RN}$ & $12 / 10-3 \mathrm{RN}$ & $12 / 17-3 \mathrm{RN}$ & $12 / 21-3 \mathrm{RN}$ & 12/23-3 RN & Meiji10 1877 & & & & \\
\hline $12 / 25-3 \mathrm{RN}$ & & & & & $03 / 31-50 \mathrm{NS}$ & 07/07-102 NS & $09 / 15-138$ NS & 11/17-175 NS & \\
\hline Meiji20 1887 & & & & & Mejij11 1878 & & & & \\
\hline $01 / 05-3 \mathrm{RN}$ & $01 / 08-3 \mathrm{RN}$ & $01 / 12-3 \mathrm{RN}$ & $01 / 15-3 \mathrm{RN}$ & $01 / 18-3 \mathrm{RN}$ & $01 / 23-23 \mathrm{NS}$ & $06 / 08-171$ NS & 09/04-271 NS & 09/21-291 NS & 10/02-303 NS \\
\hline $01 / 20-3 \mathrm{RN}$ & $01 / 22-3 \mathrm{RN}$ & $01 / 26-3 \mathrm{RN}$ & $01 / 29-3 \mathrm{RN}$ & $02 / 01-3 \mathrm{RN}$ & \begin{tabular}{|l|l|} 
Meiji12 1879 \\
\end{tabular} & & & & \\
\hline $02 / 06-3 \mathrm{RN}$ & $02 / 09-3 \mathrm{RN}$ & $02 / 18-3 \mathrm{RN}$ & 02/23-3 RN & 02/26-3 RN & $01 / 15-15$ NS & $02 / 19-87$ NS & 03/29-99 NS & 04/05-107 NS & 04/16-119 QS \\
\hline 03/03-3 RN & 03/05-3 RN & $03 / 12-3 \mathrm{RN}$ & $03 / 18-3 \mathrm{RN}$ & $03 / 20-3 \mathrm{RN}$ & $04 / 23-127$ NS 1 * 1 & $04 / 26-131$ QS & $04 / 30-135$ NS $* 2$ & $05 / 07-143$ NSQ & $05 / 10-147 \mathrm{NSQ} *$ \\
\hline $03 / 30-3 \mathrm{RN}$ & $04 / 05-3 \mathrm{RN}$ & 04/09-3 RN & 04/13-3 RN & $04 / 16-3 \mathrm{RN}$ & \begin{tabular}{|l|}
$05 / 14-151 \mathrm{NSQ}$ \\
\end{tabular} & 05/21-159 NSQ ${ }^{*} 5$ & $505 / 24-163 \mathrm{NSQ}$ & $\mid 05 / 28-167 \mathrm{NSQ} Q 600$ & $06 / 11-183$ NS 37 \\
\hline 04/20-3 RN & 04/26-3 RN & 05/06-3 RN & 05/10-3 RN & $05 / 12-3 \mathrm{RN}$ & 06/25-199 NS & $07 / 02-207$ NS & 07/05-211 NS & $07 / 12-219$ NS $* 8$ & $07 / 19-227$ NS \\
\hline $05 / 15-3 \mathrm{RN}$ & 05/19-3 RN & 05/22-3 RN & 05/26-3 RN & $05 / 31-3 \mathrm{RN}$ & 07/23-231 TS & 07/26-235 TS & $07 / 30-239 \mathrm{NS}$ & $08 / 02-243$ NS & $08 / 16-259$ NS \\
\hline $06 / 02-3 \mathrm{RN}$ & $06 / 08-3$ RN & $06 / 10-3$ RN & 06/14-3 RN & $06 / 18-3$ RN & 08/23-267 TS & 08/27-271 NS 09 & $909 / 17-295$ NS & $09 / 27-307$ NS & 10/01-311 NS \\
\hline $06 / 21-3 \mathrm{RN}$ & $06 / 23-3 \mathrm{RN}$ & $07 / 15-3$ RN & $07 / 20-3 \mathrm{RN}$ & 07/29-3 RN & $10 / 08-319$ NS & $10 / 25-339$ NS 10 & $0 \mid 10 / 29-343$ NS & $11 / 05-351$ NS & $11 / 08-355$ NS \\
\hline $08 / 10-3 \mathrm{RN}$ & $08 / 12-3 \mathrm{RN}$ & 09/15-3 RN & 10/09-3 RN & $10 / 20-3 \mathrm{RN}$ & $11 / 15-363$ NS & $11 / 26-375 \mathrm{NS}$ & $12 / 06378$ NS & 12/10-391 NS 08 䅈 & $12 / 13-395$ NS \\
\hline $10 / 22-3 \mathrm{RN}$ & $11 / 05-3 \mathrm{RN}$ & $11 / 10-3 \mathrm{RN}$ & $11 / 17-3 \mathrm{RN}$ & $11 / 26-3 \mathrm{RN}$ & 12/20-403 NS & $12 / 27-411$ NS & & & \\
\hline $12 / 02-3 \mathrm{RN}$ & $12 / 07-3 \mathrm{RN}$ & $12 / 11-3 \mathrm{RN}$ & $12 / 14-3 \mathrm{RN}$ & $12 / 16-3 \mathrm{RN}$ & Mejij13 1880 & & & & \\
\hline $12 / 21-3 \mathrm{RN}$ & $12 / 23-3 \mathrm{RN}$ & $12 / 25-3 \mathrm{RN}$ & & & $01 / 04-3$.NS & $01 / 31-35$ NS & $02 / 04-39$ NS & $02 / 11-55$ NS & 02/25-59 NS \\
\hline Meiji21 1888 & & & & & 03/06-71 NS & $03 / 19-87 \mathrm{NS}$ & 03/24-91 NS & $03 / 27-95$ NS & 04/07-103 NS \\
\hline $01 / 06-3 \mathrm{RN}$ & $01 / 08-3 \mathrm{RN}$ & $01 / 11-3 \mathrm{RN}$ & $01 / 13-3 \mathrm{RN}$ & $01 / 15-3 \mathrm{RN}$ & 04/17-115 NS & $04 / 24-123$ NS & 05/01-131 NS & 05/08-139 NS & $05 / 22-155$ NS \\
\hline $01 / 17-3 \mathrm{RN}$ & $01 / 22-3 \mathrm{RN}$ & $01 / 25-3 \mathrm{RN}$ & $01 / 27-3 \mathrm{RN}$ & 02/04-3 RN & 05/26-159 NS & $05 / 29-163 \mathrm{NS}$ & $06 / 02-167$ NS & 06/05-171 NS & 06/19-187 NS \\
\hline $02 / 08-3 \mathrm{RN}$ & 02/14-3 RN & 02/16-3 RN & 02/19-3 RN & $02 / 22-3 \mathrm{RN}$ & 06/03-100 NS & $07 / 17-219$ NS & $07 / 24-227$ NS & $08 / 07-243$ NS & $08 / 11-247$ NS \\
\hline $02 / 24-3 \mathrm{RN}$ & $02 / 26-3 \mathrm{RN}$ & $03 / 06-3 \mathrm{RN}$ & $03 / 11-3 \mathrm{RN}$ & $03 / 14-3 \mathrm{RN}$ & \begin{tabular}{|l}
$08 / 21-259$ NS \\
\end{tabular} & 09/04-275 NS & $09 / 15-287$ NS & $09 / 22-295 \mathrm{NS}$ & $09 / 29-303$ NS \\
\hline $03 / 18-3 \mathrm{RN}$ & $04 / 13-3 \mathrm{~N}$ & $04 / 26-3 \mathrm{RN}$ & $06 / 23-3 \mathrm{RN}$ & $07 / 11-3 \mathrm{RN}$ & $10 / 02-307$ NS & $10 / 06-311 \mathrm{NS}$ & 10/13-319 NS & $10 / 16-323$ NS & $10 / 27-335$ NS \\
\hline $07 / 11-3 \mathrm{RN}$ & $07 / 22-3 \mathrm{RN}$ & 08/09-3 RN & $08 / 17-3 \mathrm{RN}$ & $08 / 26-3 \mathrm{RN}$ & $11 / 13-251$ NS & $11 / 24-363 \mathrm{NS}$ & 12/01-371 NS & $12 / 08-379 \mathrm{NS}$ & $12 / 15-387$ NS \\
\hline $09 / 02-3 \mathrm{RN}$ & 09/05-3 RN & $11 / 21-3 \mathrm{RN}$ & $11 / 27-3 \mathrm{RN}$ & $12 / 01-3 \mathrm{RN}$ & $12 / 22-395$ NS & $12 / 25-399 \mathrm{NS}$ & & & \\
\hline $12 / 22-3 \mathrm{RN}$ & & & & & Mejij14 1881 & & & & \\
\hline Mejij22 1889 & & & & & $01 / 04-3$ NS & $01 / 12-11$ NS & $01 / 19-19 \mathrm{NS}$ & 01/26-27 NS & $02 / 19-55$ NS \\
\hline $01 / 13-3 \mathrm{RN}$ & $01 / 17-3 \mathrm{RN}$ & $02 / 03-54$ RN & $02 / 07-\mathrm{S} 4 \mathrm{SN}$ & $02 / 17-\mathrm{S} 4 \mathrm{RN}$ & $02 / 23-59$ NS & $03 / 02-67 \mathrm{NS}$ & $03 / 12-79$ NS & 04/02-103 NS & 04/20-123 NS \\
\hline $02 / 22-54$ RN & $03 / 08-54$ RN & $03 / 10-54 \mathrm{RN}$ & $03 / 17-\mathrm{S} 4 \mathrm{RN}$ & 03/20-S4 RN & 05/11-147 NS & $05 / 26-167$ NS & 06/08-179 NS & 06/16-191 NS & 06/25-199 NS \\
\hline $03 / 23-54 \mathrm{RN}$ & 03/26-S4 RN & $04 / 09-54 \mathrm{SN}$ & $04 / 13-54 \mathrm{RN}$ & $04 / 18-S 4$ RN & $07 / 02-207$ NS & $07 / 09-215-\mathrm{NS}$ & 07/20-227 NS & 07/23-231 NS & $07 / 30-139 \mathrm{NS}$ \\
\hline
\end{tabular}

\begin{tabular}{|l|l|l|l|l|l|}
$05 / 22-54$ RN & $05 / 25-54$ RN & $05 / 30-S 4$ RN & $06 / 04-S 4$ RN & $06 / 13-S 4$ RN \\
\hline
\end{tabular}

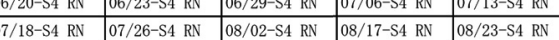

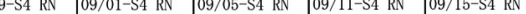
\begin{tabular}{lll|lll}
\hline $0 / 19-54$ RN & $10 / 25-\mathrm{S} 4 \mathrm{RN}$ & $11 / 09-\mathrm{S} 4 \mathrm{RN}$ & $11 / 22-\mathrm{S} 4 \mathrm{RN}$ & $12 / 07-\mathrm{S} 4 \mathrm{RN}$ \\
\hline
\end{tabular} Meiji23 1890

\begin{tabular}{|l|l|l|l|l|}
\hline $02 / 27-54$ RN & $03 / 04-S 4$ RN & $03 / 09-S 4$ RV & $03 / 13-S 4$ RN & $03 / 26-S 4$ SN \\
\hline
\end{tabular}

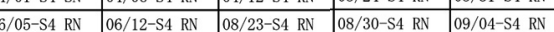

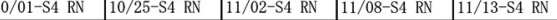
Meiji24 1891

\begin{tabular}{|l|l|l|l|l}
\hline $03 / 27-S 4$ RN & $04 / 21-S 4$ RN & $06 / 11-S 4$ RN & $07 / 09-S 4$ RN & $07 / 18-S 4$ RN \\
\hline
\end{tabular} $1 / 13-54$ RN Table 1-2 The report of "Kugisao-rui" 釘棹類の記事

\begin{tabular}{|l|l|l|l|}
\hline $03 / 31-50 \mathrm{NR}$ & $07 / 28-110 \mathrm{NR}$ & $08 / 11-118 \mathrm{NR}$ & $10 / 06-150 \mathrm{NS} * 01$ \\
\hline
\end{tabular}

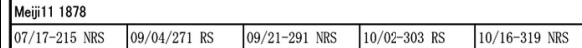
\begin{tabular}{l|l|l|l}
\hline $1 / 30-367$ NRS & $12 / 14-383$ NRS & $12 / 25-395$ \\
NRS
\end{tabular}

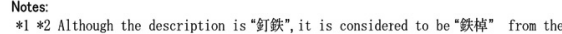

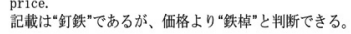

\section{釘鉄類の記事}

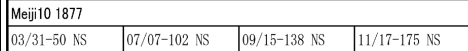

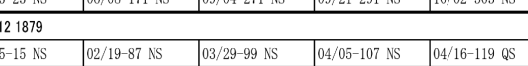

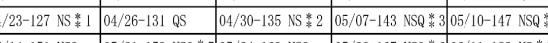

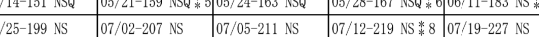

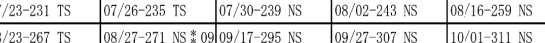

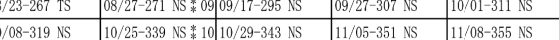

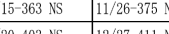

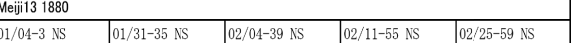

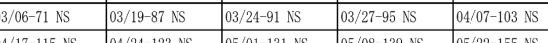

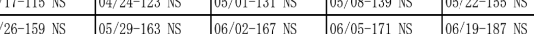
\begin{tabular}{|l|l|l|l|l|l|}
\hline $03-100$ NS & $07 / 17-219 \mathrm{NS}$ & $07 / 24-227 \mathrm{NS}$ & $08 / 07-243 \mathrm{NS}$ & $08 / 11-247 \mathrm{NS}$ \\
\hline
\end{tabular}

\begin{tabular}{|l|l|l|l|l|l}
\hline$/ 02-307$ NS & $10 / 06-311$ NS & $10 / 13-319$ NS & $10 / 16-323$ NS & $10 / 27-335$ NS \\
\hline
\end{tabular} \begin{tabular}{|l|l|l}
\hline $22-395 \mathrm{NS}$ & $1 / 2 / 25-399 \mathrm{NS}$ \\
\hline
\end{tabular}

\begin{tabular}{|l|l|l|l|l}
\hline$/ 04-3$ NS & $01 / 12-11$ NS & $01 / 19-19$ NS & $01 / 26-27$ NS & $02 / 19-55$ NS \\
\hline
\end{tabular}

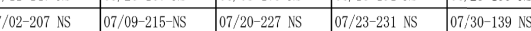

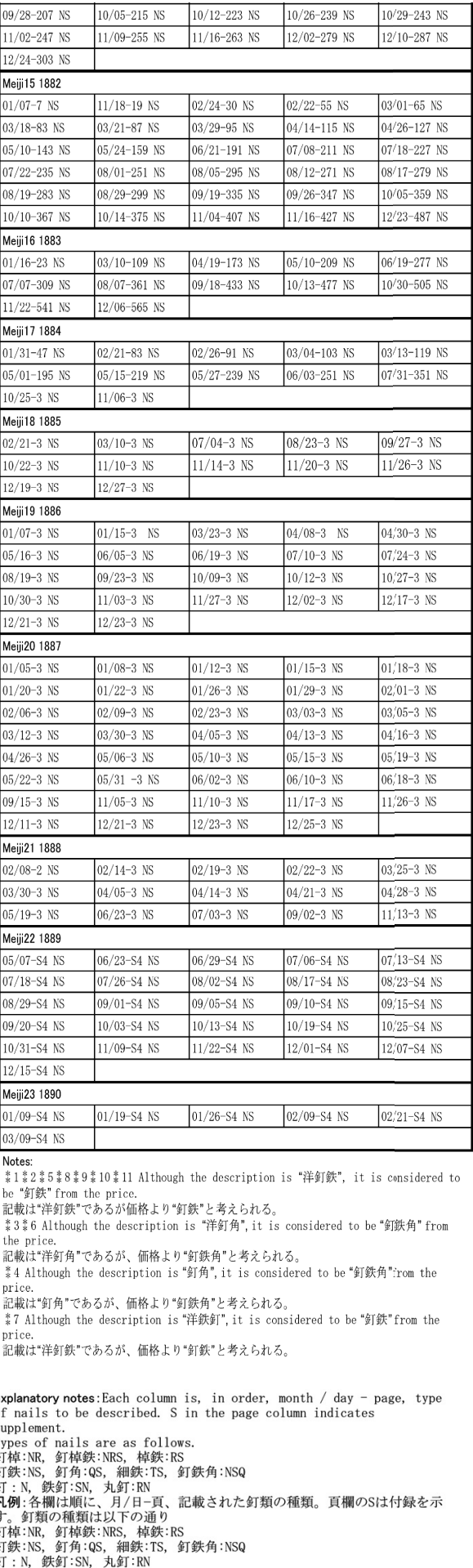

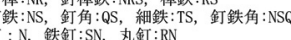

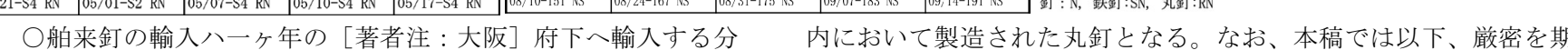

にても三十二万○八○○円余の金高に及びけれバ幾分か輸入を

すためこの釷を“洋鉄国産丸釗”と称する。

拒がん為当砲兵工廠にて八右製造器械を備へ続々製出せらる〉

$3-3$ 釘鉄・釘鉄角・釘角 と云う注30)

とする記事もあり、国内でもこの時期、舶来釘の輸入を阻むため、

\section{3-3-1 釘鉄類の輸入}

釪鉄類についての初見は、鉄棹と同じ明治 10 (1877) 年 3 月 31 日 既に “舶来模擬の釷”、即ち丸釷の生産が行われていたことが判明す るわけで、これらの原料として上述した、輸入された釷棹が用いら れたと考えられる。つまりここで製造された釘は、洋鉄を用いて国 付の記事に

金物八別段替リ無此程䊒売ニテ丸角鉄并二釷鉄等可也ノ価ニテ 売レタレトモ一体相場弱気丸角八百斤二付三弗占三弗五分注31) 
として見ることができる。ここでは“丸角鉄”と併記されて “鉄釷” が記されるため、釗鉄は “丸角鉄”とは区別するとの認識があった ことが分かる。以後、明治 10 (1877) 年では 7 月 7 日付の記載では 釘鉄五十噸注32)

とあり、同年 9 月 15 日付にも

釬鉄六十噸注 33

同年 11 月 17 日付には

釘鉄二万五千斤注 34

とあり、 1 斤 $=0.6 \mathrm{~kg}$ とすれば 1.5 トンの輸入を確認できる。

そして、以後は記載が多く、明治 $11(1878)$ 年には 5 件、明治 12 (1879) 年は 42 件 (後述する釷角 5 例、細鉄 5 例、釬鉄角 1 例を含 む)、明治 $13(1880)$ 年は 42 件とするものが最も多く、明治 23(1890) 年 3 月 9 日付注35) の記載まで確認ができる。

輸入先は明治 11(1878)年 6 月 8 日付の記載に 釷鉄白耳義産ハ少 $/$ 取引アリ注36)

Table 2 Number of the nail articles in "Chugai" paper 『中外』紙における釘類記事の数量

\begin{tabular}{|c|c|c|c|c|}
\hline \multirow{2}{*}{\multicolumn{2}{|c|}{ year }} & \multirow{2}{*}{$\begin{array}{l}\text { tetukugi } \\
\text {-rui } \\
\text { 鉄釘類 }\end{array}$} & $\begin{array}{l}\text { kugitetu } \\
\text {-rui }\end{array}$ & \multirow{2}{*}{$\begin{array}{l}\text { saokugi } \\
\text {-rui } \\
\text { 棹釘類... }\end{array}$} \\
\hline & & & 釘鉄類 & \\
\hline Meiji10 & 1877 & 2 & 5 & 5 \\
\hline Meiji11 & 1878 & 2 & 5 & 6 \\
\hline Meiji12 & 1879 & 5 & 43 & 2 \\
\hline Meiji13 & 1880 & 0 & 42 & \\
\hline Meiji14 & 1881 & 1 & 36 & \\
\hline Meiji15 & 1882 & 5 & 30 & \\
\hline Meiji16 & 1883 & 10 & 12 & \\
\hline Meiji17 & 1884 & 28 & 12 & \\
\hline Meiji18 & 1885 & 31 & 12 & \\
\hline Meiji19 & 1886 & 41 & 22 & \\
\hline Meiji20 & 1887 & 63 & 39 & \\
\hline Meiji21 & 1888 & 36 & 15 & \\
\hline Meiji22 & 1889 & 51 & 26 & \\
\hline Meiji23 & 1890 & 26 & 6 & \\
\hline Meiji24 & 1891 & 16 & 0 & \\
\hline
\end{tabular}

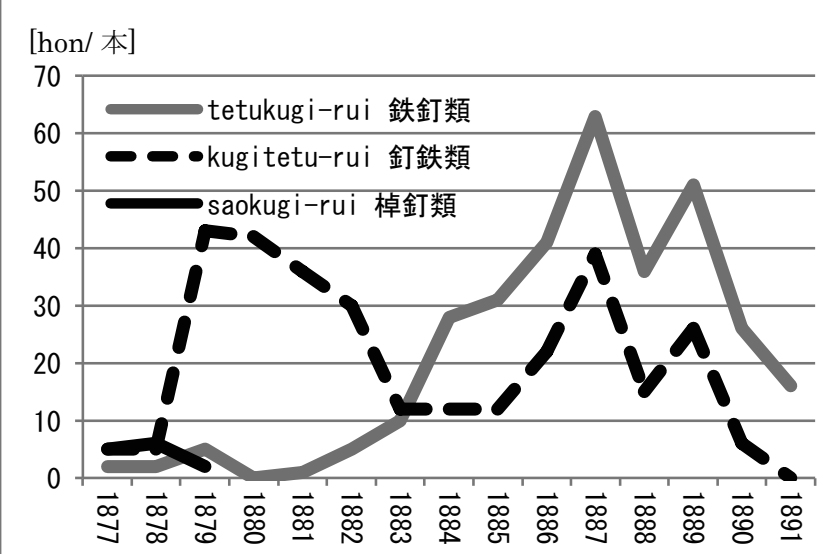

Fig. 1 Number of the nail articles in "Chugai" paper 『中外』紙における釘類記事の数量
とあることから、この時期には白耳義から輸入と確認できる。 3-3-2 釘鉄に類似する製品の記載

“釬鉄”について明治 11 (1878) 年の記載では単に“釘鉄”とのみ 記していたものが、明治 12 (1879) 年 6 月 25 日付の記載では

釘鉄三厘十五多注37)

とあり、これが以後の釘鉄類に対する商況における記載の定番の形 式となっている。但し、これ以前の期間では名称や記載が一定せず、 検討が必要である。明治 12 (1879) 年 5 月 14 日付の記載では

釘鉄角三厘十五多五分注 38$)$

とする記載があり、釘鉄が角材であったことを伺わせ、同様のもの は同年 5 月 24 日付の記載注 39$)$ にも見ることができる。ところでこの 前後では類似する記載として同年 5 月 24 日付の紙面では

洋鉄角三厘十七多注 40

とあり、同年 5 月 21 日付の記載にも

洋鉄釷角三厘十五斥注 41$)$

とするものがある。記載の方法はいずれも、当時の “鉄釷”に対す る記載方法とは異なるものの、明治 12 (1879) 年 5 月 14 日付におけ る “釘鉄”に対する記載方法に則るため、これらも“釷鉄角”、即ち 釘鉄類についての記載と考えた。

類似する記載として明治 12 (1879) 年 4 月 16 日付の商況に

洋鉄一メ目二付釷角三厘十七多 ${ }^{\text {注 } 42)}$

10 日後となる明治 12 (1879) 年 4 月 26 日付の記載に

釷角三厘十七多 五分注43)

とするものがあった。これらの記載方法もこの後に定番となる “釬 鉄”に則るため、この “釷角” も前述の “釘鉄角”を示し、やはり 釘鉄類に属するものと考えた。

また、明治 12 (1879) 年 7 月 19 日付の記載には

細鉄三厘十四多五分注 44$)$

とするものを見ることができる。以後、“細鉄” は同年 8 月 23 日付 の記載まで 5 例を見ることができ、この期間には重複して “釘鉄” の記載は確認できないため、この “細鉄”も “釘鉄”と判断した。 3-3-3 釘鉄類とその用途

以上より、“釘鉄”とは、角材の細い形状をしており、これが少な くとも明治 10(1887) 年から明治 23(1890) 年に渡って継続的に輸入 されていたことになる。それでは、“釬鉄”とは、どのように用いら れたのであろうか。

従来、輸入された細線状の角断面を持つ鉄材について、福本都治 は和釘の製造について、

明治期になると輸入された細線状の角断面をもつ鉄材、すなわ

ち「線香鉄」が代用され、大正期まで製造された注45)

とする。また、先行して村松貞次郎も

明治初年になっても、これら伝統的な和釘の生産はより活発に 行われ、「㫫觔」、「線香鉄」などと称寸る細線状の鉄を外国から 輸入しては和釷を生産するほどであった注46)

として、明治時代から大正時代に及ぶまで、輸入された洋鉄である “線香鉄”などと呼ばれるものを原料として角釗の製造がなされた ことを指摘している。また、和釘の生産地の側となる、新潟県の燕 における資料では

安政の開国で海外と通商されるに及び、手工業製鉄の原料であ る一名「線香鉄＝並角」と呼ばれる細線状の鉄材が輸入され、 
和釘と洋釗との交代期が始まりました。長さ六尺、六貫八百多 を一束として、二厘角から三分角まで(価格は一貫为銀十二多) あり、小割りからすぐ釷を造ることになり、続いて丸釷が輸入 されました注47)

とする記載がある。この資料では線香鉄＝並角は、細線状の鉄材で あり、長さ 6 尺 $(1.8 \mathrm{~m})$ 、重さ 6 貫 800 多 $(25.5 \mathrm{~kg})$ で、 2 厘角 $(0.6 \mathrm{~mm})$ から 3 分角 $(9 \mathrm{~mm})$ の材料を 1 束として、これを小割にすることで角 釘が造り出されたとする。

つまり以上の指摘から、“線香鉄” “並角”とされるものが、断面 形状などから、上述した “釷鉄” に当たると考えられ、明治時代に は、輸入された洋鉄である釘鉄類によって角釘の製造が広範になさ れていたことになる。なお、厳密を期すため、この時代に海外から 輸入された “釘鉄”によって、日本国内で製造された角釷を、本稿 では以後、“洋鉄国産角釷”と記す。

\section{4 明治時代前半おける釘の流通}

\section{4-1 明治時代前半おける釘流通の動向}

明治9 (1876) 年の創刊から明治24(1891) 年の『中外』紙における横 浜商況における “鉄釬類”、“釷棹類”、“釘鉄類” の掲載件数をまと めたものがTable 2、Fig. 1となる。1件当たりの記載は輸入量を示 寸ものではないため、これらは出回った製品などの数量を正確に示 すものではないが、全体の動向を示すものと考える。

Table 2、Fig. 1によれば明治10 (1877) 年には、洋釘と一般に呼称 される輸入丸釘が従来の報告よりも多数輸入されていたことを確認 できる。また、同時に“洋鉄国産丸釷” の原料と考えられる棹鉄類、 “洋鉄国産角釗” の原料之なる釘鉄類の輸入も既に確認できる。そ して明治12 (1879) 年以後、釘鉄類の輸入件数が一気に激増するが、 これは結果として “洋鉄国産角釷” 生産の増大を示す。つまり、明 治10 (1877) 年代前半において “輸入丸釘” や “洋鉄国産丸釘”によ りいわゆる“丸釷”が一定量は流通していたものの、“洋鉄国産角釗” の増大により、多数の角釷が市場に流通したと判断できる。

一方、明治 15 (1882) 年以後、“鉄釷類” の輸入が漸増し、更に明治 17 (1884) 年以後、掲載件数では “鉄釷類” が “釷鉄類”を逆転し、 以後、掲載件数は “鉄釷類” が “釷鉄類” の凡そ2倍程で移行してい る。これを釷類の流通面から考えると、明治10 (1877) 年代後半は、 “洋鉄国産角釷” が国内で一定数量確保されつつも、“輸入丸鎬”が 広く流通を始め、その結果、建築の現場では角釘と丸釘の併用が起 こったことになる。

つまり、これが、かつて著者等が報告した明治10(1877) 年代後半 における全国的な和釷と洋釷の併用参考2) の状況なる。但し、㛜密に 言えば、この時代に流通した和釷とは “洋鉄国産角釗”であったこ とになる。

\section{4-2 明治時代初期おける和釘価格の動向と釘の利用}

近世末期から近代初期の期間に関わる和釷価格の動向は、宮本又 次らによりまとめられた『近世大阪の物価と利子』注48) に示されて いる。この資料は、釷商であった今西佐兵衛の帳簿から查出した注49) ものであり、今西商店は明治時代中期には安堂寺橋通に位置し、洋 釘商及び金物商を名乗った注50)。この資料から明治時代初期の部分 を見ると、明治12 (1879) 年における釷大5寸の価格0.68円は、明治 7 (1874) 年の1.35円に比較して半額以下となっている注51)。厳密に言
えば、物価を考慮すれば1/2.7に下落している注52）ものの、従来、そ の理由は示されない。

ここで考えられる価格下落の理由は、上述した“洋鉄国産角釷” の生産が本格化したためと言えよう。この資料で見る限り、角釗の 価格は明治7 (1874) 年を頂点とし、以後下落したと見ることができる。

つまり、和釘の価格について前稿まででは明治8 (1875) 年における 開智学校の見積書を用いたが、この時期、和釘一角釷の価格は最も高 く、以下、“洋鉄国産角釗” の普及により和釗の価格は下落したと言 える。つまり、和釘一角釘の価格低下により、明治10 (1877) 年代後半 における和釗と洋釷の市場における併存、つまり建築現場における 和釷と洋釗の併用が可能であったと考える。

\section{5 『中外』紙に見る“輸入丸鎬”の呼称}

『中外』紙の記載によれば、輸入された釘、即ち “輸入丸釷” の 呼称は、既に述べたように明治10 (1877) 年6月 23 日の段階では輸入品 の欄においては単に “釷” 注53) と記され、明治11(1878) 年1月16日 の紙面でも “鉄鎬”注54)などとされるに留まったが、明治12(1879) 年4月 30日の記事で初めて “洋鉄釗”注55)、明治12(1879) 年5月28日 には“鉄丸釗”注56) とされた。そして単独で “丸釬”とする呼称は 明治15(1882) 年5月10日における記事注57)が初見で、以後は “丸釷” の呼称が一般的となった。

一方、同時期における他紙の記載を見ると、明治 13 (1880) 年 3 月 1 日付『朝野新聞』注58)では

○府下を始め諸国にて使用寸る釷八十中の七八まで上総釷なる に近来製造㢈悪に流れ為めに舶来釷を使用する者日に多き故之 を改良して西洋釷の輸入を防がんと《以下略》 として同一の記事の中で “舶来鎬” と“西洋鎬” の語が併用される。 また、明治 $13(1880)$ 年 2 月 13 日注59)、明治 $13(1880)$ 年 3 月 14 日付『朝 日新聞』注60) には “舶来釷”、明治13(1880) 年10月26日付『朝日新聞』 では “西洋釷” 注61) とする呼称が併存する。但し、続く明治15 (1882) 年10月13日付の『朝日新聞』には“洋釷” 注62) とあり、いわゆる “洋 釷”の呼称は、“西洋釘” の省略と考えることができ、明治15(1882) 年頃からの呼称と考えることができる。

一方、明治16 (1883) 年8月 11 日付『朝日新聞』では “舶来丸釘” 注 63) とあるが、“丸釘”の記載は上述した『中外』紙の記事と前後する もので、丸釷の呼称はこの頃から一般化したとすることができる。

\section{6 さいごに}

『中外』紙などに掲載された横浜商況の記載により、明治時代前 半における洋釷の普及について考察を行うとともに、角釗と丸釷が 併用された背景を考察し、明らかとなるのは以下の諸点である。

1 ) 明治 10 (1877) 年代から明治 20 (1887) 年代半ばにおける『中外』 紙の横浜商況に掲載された釷の記載を通読すると、この期間では 釘類として “鉄釷類”、“釷棹類”、“釷鉄類”を見ることができる。

2 ) “鉄釘類”では丸釷が明治10 (1877) 年には少なくとも2件、輸入 取引されたことが確認できた。

3 ）“釷棹類”とは同時代の英字紙に “Nai1-rod”とされ、これを 材料として丸釘、即ち洋鉄国産丸釘が製造された考えられる。

4 ）“釬鉄類”の掲載数は明治12 (1879) 年以後に激増し、これを原 料として“洋鉄国産和釷”が製造されたと考えることができる。 
5 ）この期間における釘流通の動向を見ると、明治10(1877)年代前 半には洋鉄国産和釘の製造伸張及び価格低減があり、一方、明治 10 (1877) 年後半は、洋釘一丸釘の輸入が激増し、この期間には和釘 と洋釷の併用を見ることができたと考える。

6 ) 輸入された釘に対す “丸鎬”の呼称は、管見では明治12 (1879) 年5月28日付『中外』紙が初見であり、明治15(1882)年頃から一般 化した。また、“洋釷”の呼称は“西洋釗”の省略と見ることが でき、この呼び名も明治15(1882)年頃から一般化したとすること ができる。

\section{参考文献}

1) YASUDA, Z. :Kugi, 1916.12 (in Japanese) 安田善三郎: 釘、1916. 12

2) HIRAYAMA, I. , KIMURA, T., MIFUNE, T. , UMMEJIMA, 0., NISHIZAWA, K. , STUDY ON THE BUILDINGS USED THE JAPANESE NAIL AND THE WESTRN NAIL TOGETHER, AIJ Journal of Technology and Design 51, pp. 767-770, 2016. 6 (in Japanese)

平山, 木村勉, 御船達雄, 梅嶋修, 西澤哉子: 和釷と洋釘を併用する建物、 日本建築学会技術報告集 51 , pp. 767-770，2016. 6

3) HIRAYAMA, I., STUDY ON THE USE AND THE PRICE OF THE NAIL TO WATCH IN THE ARCHITECTURAL DOCUMENTS OF THE KAITI-GAKK0, Nagaoka Institute of Design Bulletin 15, pp. 65-70, 2018.3 (in Japanese)

平山：開智学校の建築資料に見る釘の使用と值段, 長岡造形大学紀要 15 , pp. $65-70,2018.3$

4) HIRAYAMA, I., STUDY ON THE CONVERSION FROM THE JAPANESE NAIL TO THE WESTERN NAIL IN TERM OF PRICE, Journal of Architecture and Planning (Transactions of AIJ) 757, pp. 653-659, 2019.3(in Japanese) 平山：価格から見た和釘から洋釗への転換, 日本建築学会計画系論文集 757, pp. 653-659, 2019. 3

5) HIRAYAMA, I., STUDY ON THE PRICE OF THE WESTERN NAIL IN THE MIDDLE OF MEIJI 10 (1877) 'S TO THE MIDDLE OF MEIJI 20 (1887) 'S SEEN IN THE BUSINESS SITUATION OF “TYUGAI-BUKKA-SINPPO, Journal of Architecture and Planning (Transactions of AIJ) 764, pp. 2195-2201, 2019.10 (in Japanese)

平山：『中外物価新報』などの商況にみる明治 10(1877) 年代半ばから明治 20 (1887) 年代半ばにおける洋釘の価格, 日本建築学会計画系論文集 764 , pp. 2195-2201, 2019. 10

\section{注}

注1）日本新聞社社史編纂室：日本経済新聞八十年史、 $55 \sim 59$ 頁、昭和 31 (1956). 12。『中外商業新報』との改題は明治 22 (1889) 年 1 月 27 日の 2049 号からとする。

注 2) 松本市: 史料開智学校 6、平成 7 (1995). 2、参考文献 3)

注 3) 大阪大学物価史研究会: 明治期大阪卸売物価資料 (4)、大阪経済学 30-1、 120 191 頁、昭和 55(1980). 6

注 4）参考文献 1） 117 頁

注 5) 村松貞次郎: 日本建築技術史、151～152 頁、地人書館、昭和 34 (1959). 11、 も参考文献 1) と同内容を記すに留まる。

注 6）梅本二郎：釷とともに歩んだ 120 年、19 頁、平成元（1989）.10

注 7) 公益財団法人：文化財建造物保存技術協会：重要文化財旧鶴岡警察署 庁舎保存修理工事報告書、平成 30 (2018).3、は参考文献 2) の執筆後にまと められた報告書で、同書によれば 199〜201 頁において建物は明治 17 (1884) 年 11 月の竣功で、角釘と丸釗の併用が認められることを報告する。

注 8) 商况社：中外物価新報、明治 10 (1877).6/23、59 頁

注 9）商况社：中外物価新報、明治 $10(1877) .12 / 25 、 187$ 頁

注10）商况社：中外物価新報、明治 $11(1878) .1 / 16 、 15$ 頁

注11）商况社：中外物価新報、明治 $11(1878) .1 / 23 、 23$ 頁

注12）商况社：中外物価新報、明治 12 (1879).4/23、127 頁

注13) 商况社：中外物価新報、明治 $12(1879)$. 4/30、135 頁

注14）商况社：中外物価新報、明治 $12(1879) .5 / 7 、 143$ 頁

注15）商况社：中外物価新報、明治 12 (1879). 10/1、311 頁

注16）商况社：中外物価新報、明治 12 (1879). 5/28、167 頁

注17）商况社：中外物価新報、明治 $12(1879) .12 / 10 、 391$ 頁
注18）商况社：中外物価新報、明治 14(1881).11/16、263 頁

注19）商况社：中外物価新報、明治 $10(1877) .3 / 31 、 50$ 頁

注 20）商况社：中外物価新報、明治 $10(1877) .7 / 28 、 110$ 頁

注 21) 竹林滋 : 新英和大辞典 6 版、1867 頁、平成 14 (2002). 3、によれば、(1)

ピクル［東洋諸国で用いる重量の単位 $=100$ catties. ］(2)（中国の）担 [= 100 catties， $60.48 \mathrm{~kg}$ 、現在は $50 \mathrm{~kg}$ に換算]、とある。

注 22）商况社：中外物価新報、明治 11(1878).7/17、215 頁。なお、“ベルジ ユム”は向かって右側に二重傍線が引かれる。ベルジュムとは “Belgium” であり、ベルギーの正式名称の音読となる。

注 23）商况社：中外物価新報、明治 11 (1878). 11/30、367 頁 注 24）商况社：中外物価新報、明治 11 (1878). 11/30、367 頁 注 25）商况社：中外物価新報、明治 11 (1878). 12/28、191 頁 注 26）商况社：中外物価新報、明治 10 (1877). 11/17、175 頁 注 27) 日本国語大辞典第二版編集委員会 : 日本国語大辞典第二版 5、1361 頁、 平成 13 (2001). 5

注 28） A. W. Hansard：THE JAPAN HERALD.、元治元 (1864).4/16、214 頁、が 初見。平山ほか : 洋釘の輸入を示寸元治元 (1864) 年 4 月の記録 和歌山県 橋本市中心市街地の町と町家の調査研究 その 174 、日本建築学会大会学術 講演梗概集、建築歴史・意匠 847～848 頁、令和元 (2019).7、に詳しい。

注 29）朝日新聞社：朝日新聞、明治 $13(1880) .2 / 13 、 1$ 頁。なお、関連する 記事が、同紙の明治 $13(1880)$. 10/26、1 頁、にも見ることができる。

注 30）朝日新聞社：朝日新聞、明治 $13(1880) .3 / 14 、 1$ 頁 注 31）商况社：中外物価新報、明治 $10(1877) .3 / 31 、 50$ 頁 注 32) 商况社：中外物価新報、明治 10 (1877). 7/7、102 頁 注 33） 商况社：中外物価新報、明治 $10(1877) .10 / 9 、 138$ 頁 注 34）商况社：中外物価新報、明治 10 (1877). 11/17、174 175 頁 注 35）商况社：中外物価新報、明治 $23(1890)$. 3/9、付録 4 頁 注 36) 商况社：中外物価新報、明治 $11(1878) .6 / 8 、 171$ 頁 注 37）商况社：中外物価新報、明治 12 (1879).6/25、199 頁 注 38) 商况社：中外物価新報、明治 12 (1879). 5/14、151 頁 注 39) 商况社 : 中外物価新報、明治 12 (1879). 5/24、163 頁 注 40）商况社：中外物価新報、明治 12 (1879). 5/7、143 頁 注 41）商况社：中外物価新報、明治 12 (1879). 5/21、159 頁 注 42) 商况社：中外物価新報、明治 $12(1879)$. 4/16、119 頁 注 43） 商况社：中外物価新報、明治 12 (1879).4/26、131 頁 注 44）商况社：中外物価新報、明治 12 (1879).4/26、227 頁 注 45）福本都治：和釷から洋釘一 製釘技術の転換、住と建築 497、5 頁、 平成 14 (2002). 5

注 46）村松貞次郎：日本建築技術史、151 頁、前掲。なお、村松はこの記載 に対して根拠は示してはいない。

注 47）神保新一：大川のほとり、72 頁、昭和 42 (1967). 11

注 48) 大阪大学物価史研究会 宮本又次: 近世大阪の物価と利子、335 頁、昭 和 33 (1958). 8

注 49) 大阪大学物価史研究会 宮本又次: 近世大阪の物価と利子、111 頁、前 掲

注 50）白崎五郎七：日本全国商工人名録、315 頁、明治 25 (1892).4

注 51）併記される釬並 4 寸も 1.27 円から 0.60 円人下落する。

注 52) 大里勝馬：明治以後本邦主要経済統計、76 頁、昭和 41(1966).7、に

おける卸売物価係数の内、明治元 (1868) 年以来の数值を記載する朝日新聞 社による明治元 (1868) 年を 100 とした係数を用いた。これによると明治 7 (1874) 年は 143 、明治 12 (1879) 年は 145 とある。

注 53）商况社：中外物価新報、明治 $10(1877) .6 / 23 、 59$ 頁 注 54）商况社：中外物価新報、明治 $11(1878) .1 / 16$ 、15 頁 注 55）商况社：中外物価新報、明治 $12(1879)$. 4/30、135 頁 注 56) 商况社：中外物価新報、明治 12 (1879). 5/28、167 頁 注 57）商况社：中外物価新報、明治 15 (1882). 5/10、143 頁 注 58) 朝野新聞社：朝野新聞、明治 $13(1880) .3 / 1$ 、 1 頁 注 59）朝日新聞社：朝日新聞、明治 $13(1880) .2 / 13 、 1$ 頁 注 60）朝日新聞社：朝日新聞、明治 $13(1880) .3 / 14 、 1$ 頁 注 61）朝日新聞社：朝日新聞、明治 $13(1880) .10 / 26 、 1$ 頁 注 62) 朝日新聞社：朝日新聞、明治 15 (1882). 10/13、4 頁 注 63）朝日新聞社：朝日新聞、明治 $16(1883) .8 / 11 、 4$ 頁 


\title{
STUDY ON THE DIFFUSION OF THE WESTERN NAIL AND BACKGROUND OF THE COMBINED ON THE USE OF THE JAPANESE NAIL IN THE FIRST HALF OF THE MEIJI PERIOD
}

\author{
Ikuo HIRAYAMA*1 \\ ${ }^{* 1}$ Prof., Faculty of Design, Nagaoka Institute of Design, Dr.Eng., Dr.Design
}

The author has so far considered the spread of the Western nails in the Meiji era from the viewpoint of the price. As a result, it has already shown that it was the price of a 1.5 inch long nail is $1 / 21$ in 1885, 1/50 at the end of the Meiji period, compared to the same length of the Japanese nails in 1875. By the way, the question remains as to how the nails spread before 1885. Although the authors have already reported that the Japanese nails -square nails- and the Western nails - round nails- were used together from the late Meiji 10s to the Meiji 20s, in spite of such a price difference, the reason why square nails and round nails are used together cannot be clearly shown. Therefore, this article aims to clarify the background of the combined use of square nails and round nails by examining the spread of the Western nails in the first half of the Meiji era according to the actual situation of imports.

Based on the description of the business situation in Yokohama published in "Chugai-bukka-shimpo" and "Chugai-syogyo-shimpo" (hereinafter referred to as "Chugai"), I considered the spread of the Western nails in the first half of the Meiji period. From the Meiji 10s to the mid-Meiji 20s, "kugi-tetu": nail iron, "kugi-sao" and "tetu-kugi" : iron nail were confirmed as nails based on the descriptions of nails published in the Yokohama business situation of "Chugai" papers. Of these, it was confirmed that round nails were imported at least twice in Meiji 10 for "iron nails". It can be judged that "kugi-sao" were considered to be "nail-rod" in English paper of the same era, and it was considered that round nails, the round nail made of the nail-rod as the material, the Japanese-made round nail was manufactured by Western Iron. The number of "nail irons" has increased dramatically since 1879, and Japanese nail was produced in Japan using this as the raw material. The distribution of nails during this period can be considered as follows. In the first half of the Meiji 10s, there was a reduction in prices due to the expansion of the Japanese nail production using Western iron. In addition, since the import of the Western nails, or round nails, increased sharply in the late Meiji 10s, Japanese nails and the Western nails were used together. 